\title{
In Reply: Pharmacological Venous Thromboembolism Prophylaxis in Meningioma Patients: Should it be Earlier than in Clinical Practice?
}

\author{
Emrah CELTIKCI ${ }^{1,2}$ \\ ${ }^{1}$ Yildirim Beyazit University, Yenimahalle Research and Education Hospital, Department of Neurosurgery, Ankara, Turkey \\ ${ }^{2}$ University of Pittsburgh Medical Center, Department of Neurological Surgery, Pittsburgh, USA
}

To the Editor;

$\mathrm{W}$ Te thank Yildirim and Aykan (6) for their commentary about pharmacological venous thromboembolism prophylaxis in meningioma patients.

According to the Guidelines of the American College of Chest Physicians, any intracranial operation is considered a procedure with an increased bleeding risk (4). Also in the same guidelines, any history of intracranial surgery within 3 weeks is considered as a contraindication to therapeutic anticoagulation (3). Additionally, as we mentioned in the materials and methods section, compression stockings were routinely used instead of intermittent pneumatic compression (IPC) in the department this study was conducted in, Gazi University Faculty of Medicine's Department of Neurosurgery (2). In a recent manuscript of a randomized trial, the authors concluded that IPC does not lead to a significant gain in quality-adjusted survival (3).

Yildirim and Aykan (6) also asked the reason of waiting 48 hours for thromboembolism prophylaxis after surgery. Meningiomas mostly affect the brain cortex and white matter tracts with a mass effect, which means that an ischemiareperfusion process will be present after decompression of tumor tissue. Additionally mechanical manipulation of the surgical site over the functional area can lead to a transient neurological deficit. The pathophysiology of this phenomenon is very similar in some intra-axial lesions that do not tend to invade white matter tracts such as pilocytic astrocytomas. There are reports of transient neurological deficits in the early postoperative period of non-invasive central nervous system tumors $(1,5)$. This is why we tend to wait 48 hours after surgery to see if the patient will able to mobilize or not.
Again we thank Yildirim and Aykan (6) for their contributions and comments on our study which makes our study more valuable.

\section{REFERENCES}

1. Broadway SJ, Ogg RJ, Scoggins MA, Stanford R, Patay Z, Boop FA: Surgical management of tumors producing the thalamopeduncular syndrome of childhood. J Neurosurg Pediatr 7(6): 589-595, 2011

2. Celtikci E, Kaymaz AM, Akgul G, Karaaslan B, Emmez $\mathrm{OH}$, Borcek A: Retrospective analysis of 449 intracranial meningioma patients operated between years $2007-2013$ in a single institute. Turk Neurosurg 28(1): 1-6,2018

3. CLOTS (Clots in Legs or Stockings after Stroke) Trials Collaboration: Effect of intermittent pneumatic compression on disability, living circumstances, quality of life, and hospital costs after stroke: Secondary analyses from CLOTS 3, a randomised trial. Lancet Neurol 13(12): 1186-1192, 2014

4. Kearon C, AkI EA, Comerota AJ, Prandoni P, Bounameaux H, Goldhaber SZ, Nelson ME, Wells PS, Gould MK, Dentali F, Crowther M, Kahn SR: American College of Chest Physicians. Antithrombotic therapy for VTE disease: Antithrombotic therapy and prevention of thrombosis, $9^{\text {th }}$ ed: American College of Chest Physicians Evidence-Based Clinical Practice Guidelines. Chest 141(2 Suppl): e419S-94S, 2012

5. Moshel YA, Elliott RE, Monoky DJ, Wisoff JH: Role of diffusion tensor imaging in resection of thalamic juvenile pilocytic astrocytoma. J Neurosurg Pediatr 4: 495-505, 2009

6. Yildirim F, Aykan FS: Pharmacological venous thromboembolism prophylaxis in meningioma patients: Should it be earlier than clinical practice? Turk Neurosurg 28(1):164-165, 2018 